\title{
Deal or no deal: English Devolution, a top-down approach
}

\author{
RACHEL WALl \& NoEMia Bessa VILELA
}

\begin{abstract}
A new legislative framework for devolution has been introduced into England marking a potentially significant step towards addressing the unfinished business of Labour's devolution settlement. What promised to be a bespoke and bottom-up commitment to devolution for English local government has manifested into a top-down, prescriptive and inconsistent process of agreeing the decentralisation of functions and finances to groups of principal local authorities. The paper reports on the progress of the new wave of devolution in England to date, through a review of agreed devolution deals and assesses the extent to which the current 'devolution revolution' represents the beginning of a shift away from a centralised system built from the bottom up, or looks set to result in another typically top-down reform to local government. The paper presents the initial findings of early research, which will be used to develop key research questions for a further long-term research project.
\end{abstract}

KEYWORDS: - local self-government • devolution • legislative framework $\bullet$ top-down approach $\bullet$ England

CoRRESPONDENCE AdDRESS: Rachel Wall, Ph.D. Student, De Montfort University, Leicester Business School, Local Governance Research Unit, 3.81 Hugh Aston Building, The Gateway, Leicester LE1 9BH, UK, email: p11247194@myemail.dmu.ac.uk. Noemia Bessa Vilela, researcher, Portucalense University Infante D. Henrique, Portucalense Institute for Legal Research, Rua Dr. António Bernardino de Almeida, 541/619, 4200-072 Porto, Portugal, email: noemia@uportu.pt.

DOI 10.4335/14.3.655-670(2016)

ISSN 1581-5374 Print/1855-363X Online ㄷ 2016 Lex localis (Maribor, Graz, Trieste, Split)

Available online at http://journal.lex-localis.press. 

approach

\section{Introduction}

Since the 1960s the political landscape of English local government has frequently been recast into the mould of one national government or another, as decisions regarding the size, shape and scope of local government have been subject to ideological climates, party political considerations and other vested interests (Stoker, 1991). Throughout numerous changes to the structure of local government, two things still remain clear; size matters to central government and that they continue to perceive smaller, empowered and truly local units of government as an unnecessary and overpriced luxury.

The reoorganisations of local government since the mid-1970s by successive Conservative and Labour governments have rested on assumptions and beliefs within central departments and selected external bodies (Stewart, 2014). Those beliefs are that, despite unitary local government across the rest of Europe not being the norms, large single-unit municipal authorities could deliver economies of scale, for which evidence is mixed at best (ibid; Chisholm, 2010; Elcock et al, 2010). In assessing recent developments of English local government, it is clear that while units of local government have grown in size, they have shrunk in many other aspects; functions have been removed, resources have declined, administrative workforces have been reduced while the intensity and complexity of local needs have increased significantly (Weir and Beetham 1999).

England, having remained the unfinished business of devolution, is now experiencing a devolution revolution. The current Chancellor has laid out a longterm, purportedly radical agenda for local government to build upon the progress of City deals and Growth deals - prosperity through partnerships - which were intended to increase the capacity of local civic and business leaders to identify local economic needs and promote growth. The Local Democracy, Economic Development and Construction Act 2009, made provision for the establishment of combined authorities, meaning that a group of local councils in any given area, providing there is a consensus between them, could pool appropriate responsibility and receive certain functions from central government, limited to transport and economic development. The Cities and Local Government Devolution Act 2016, introduced amendments to the 2009 Act by removing statutory limitation on which powers could be devolved and made provision for the introduction of directly elected mayors to combined authorities.

The relationship between central and local government in the United Kingdom has been interpreted by academics as problematic and in a perennial state of crisis (Jones and Stewart, 1985; Goldsmith and Page 1987; Jones and Stewart, 2002), symptomatic of which are the never-ending pieces of legislation passed that, whilst significantly impacting the function and role of local government, do very little in slowing the pace of centralisation and empowering local authorities to 
effectively govern their communities (Ibid.) Therefore it is crucial to explore the newest addition to Whitehall's collection of palliative care procedures for local government in order to determine whether English local government really is witnessing a devolution revolution.

The paper, through drawing on those devolution deals which have already been signed between combined authorities and central government, looks to report on the current process of devolution so far within this context and to highlight and discuss some of the common themes, concerns and unanswered questions such as : is this devolution at all? How can we address the opposition to mayoral governance? To what extent does this new agenda demonstrate a change, if at all, to the centralised relationship between Whitehall and our municipalities? The paper presents the initial findings of early research, which will be used to develop research questions for a further long-term research project exploring the current devolution agenda in England. The next sections of the paper will provide a brief contextual background to devolution in English local government. The third and fourth sections examine the devolution deals signed to date and holds them against the claims from central government that we are experiencing a devolution revolution. The paper concludes by examining the extent to which the current devolution agenda represents a significant shift in the relations between central and local government.

\section{Devolution?}

Devolution and Decentralisation are concepts which are often conflated and used interchangeably. Devolution has been defined, within the context of the home nations within the United Kingdom, as the transfer of power from one political authority to a subordinate political authority on a geographical basis (Bogdanor, 1999, 2001, 2009; Hazell 1999, ed. 2010). Bogdanor's use of the term power encompasses either legislative powers to create laws, or executive powers to create statutory instruments and orders, within a centrally determined legal framework (ibid). Burns et al. describe Decentralisation as the transfer of functions, tasks and responsibilities - but not necessarily power - to lower level units of government. Despite being repeatedly and misleadingly referred to as a Devolution Revolution by government and commentators, it is evident that what we are observing in English local government is not a genuine wave of the devolution of powers, but rather a fragmented and inconsistent pattern of the decentralisation of funding streams and regional projects aimed at both addressing economic growth and further streamlining of public service provision - both of which are for the benefit of political expediency at the centre.

Although we are seeing that functions and responsibilities are being devolved to local government through the establishment of combined authorities, local councils are faced with continued severity of cuts to their finances, largely 

approach

provided by the centre, which threaten the provision of even the most essential and critical local services. It is here, in the lack of fiscal devolution on offer, that the real dangers lie. While the chancellor announced late in 2015 that local authorities would be able to retain $100 \%$ of the business rates they raise locally, this still leaves local government in England with a mammoth task of balancing the books, ensuring the provision of services and meeting complex local needs in a world of no more significant Whitehall grants and a staggering lack of powers to raise its own finances locally.

While the new The Cities and Local Government Devolution Act 2016 implies a move towards stronger local government in England and a shift from the centralized Westminster model, typically what Whitehall gives it must also taketh away. The role of local authorities in the provision of education has been consistently eroded since 1944, a highlight being in the mid 1980s which saw the introduction of grant-maintained status, allowing schools to "opt out" of local authority control and receive funding directly from Whitehall (Waterman, 2014). Some 30 years later, we are now witnessing a drive by the current Education secretary to convert primary and secondary schools in England to independent, centrally funded academies, which operate outside the sphere of influence of local authorities. The Housing and Planning Act is set to have a sizably negative impact on local social housing capacity and Fire and Rescue policy is moving from the Department for Communities and Local Government into the remit of the Home Office.

We therefore have to challenge, not only Whitehall's commitment to the 'devolution revolution', but also what its motives are beneath the opaque deal making between political elites and non-elected actors; an evident absence of measurable objectives laid out for the current devolution agenda implies that this uncertainty still remains rather difficult to address, and indicates that we are experiencing an event aimed at providing political expediency, rather than a process to facilitate long-term devolution to local government; a process which is trapped fundamentally by the current Chancellor's tenure in office.

\section{The path to English devolution}

Devolution at the sub-national level at the end of the last century through to the present day has made a significant impact on the political landscape of the United Kingdom. It has not however, been a symmetrical process of devolving power; as a result of the 1997 referenda Scotland, Wales Northern Ireland have, in varying levels, seen the statutory granting of certain primary legislative powers from Westminster. England however, has thus far been omitted from the process of devolution (Greater London being an exception) and ultimately all decisions regarding the shape, role and functions of English local government remain with the centre. Until now England has remained the unfinished business of devolution 
in the United Kingdom, or as Wilson and Game (2006) coined it, 'the hole in Labour's 'devolution settlement' that has yet to bring elected, democratic government to the regions of England (Wilson and Game, 2006: 14) - or indeed to England as a nation.

The Local Government Act 2000, which largely rested on the recommendations of the Heseltine Review of local government in 1991, saw the end of what was perceived to be an inefficient and ineffective committee-based system, and required local authorities in England (and Wales) to review their executive arrangements. The Act provided local authorities with a menu of political executive options, one of which they were required to adopt; Leader and cabinet executive, Mayor and cabinet executive and the now repealed option of Mayor and council manager executive (Leach, 2006). The office of an elected mayor was a novelty to local government in the United Kingdom and presented a new opportunity for the electorate to now 'choose for themselves the individual politician they wish to hold the political leadership of the council'- a choice previously gifted only to locally elected councillors (Copus, 2006: 29). The direct election of a strong, individual leader presented a new means through which to enhance accountability and provide transparent leadership (Lowndes and Leach, 2004).

The political executive model imposed by the Act represented a 'fundamental change' for local government in which central government sought to emphasise a move the elected mayoral model, a theme seen to continue within the Localism Act 2011 which sought to 'heighten the powers of the leader to give the position an authority close to the mayoral model' through emphasizing the role of the individual rather than the role of the collective cabinet' (Stewart, 2014: 842).

In 2004 referendums were proposed under the provisions of the Regional Assemblies (Preparations) Act 2003 for the North East of England. Although three referendums were originally envisaged, only one took place. The referendum concerned the devolution of specific political powers from Parliament to regional assemblies in North East England, North West England and Yorkshire and the Humber. Voters rejected the proposal on 4 November 2004, further halting the government's proposed plans for devolution.

Following the outcome of the Scottish independence referendum in 2014 that delivered a 'no' vote to leaving the United Kingdom, the then Prime Minister, David Cameron, announced that alongside proposals for additional devolution to Scotland, Wales and Northern Ireland, conversations would begin to identify the best way to 'empower' the cities of England. That announcement followed the independent report by Lord Heseltine in 2012, No stone unturned: in pursuit of growth, which, rather oddly under the name of 'Localism' made 89 recommendations to help industry and reported that in order for the government to 

approach

address 'a lack of strategy for growth and wealth creation', power needed to move away from London and to English regions.

In a continued pursuit for local economic growth in England, the Coalition Government (2010-2015) took a number of steps to devolve powers and funding to local government; the Regional Development Agencies (RDAs) introduced by the Labour government in 1999 were abolished and replaced with Local Enterprise Partnerships (LEPs), whose remit was to define local economic priorities and lead economic growth and job creation within their local areas, and a number of bilateral 'city deals' were produced and agreed between central government, local councils and LEPs. An addition to these changes was a continuation of the promotion of directly elected mayors for local authorities in major cities, although most of the cities in question rejected the mayoral model in a series of referendums previously held in 2012 .

A number of reports followed, including Decentralisation Decade (Cox et al., 2014) and Devo Max - Devo Manc (Blond \& Morrin, 2014) all placing a collective priority on emphasising the need to find further efficiencies in the provision of public services and stimulate local economic growth at a time which saw continuing reductions in local government funding. The changes proposed were for the decentralizing of powers over specific policy areas coupled with the transfer of relevant budgets, additional local taxation powers and the creation of both combined authorities and directly elected mayors.

The legal framework within which these changes were to be implemented has taken the form of The Cities and Local Government Devolution Act 2016. The Act gave effect to the Greater Manchester Combined Authority while providing statutory authority for the rest of England to enter into negotiations with The Cities and Local Growth Unit, HM Treasury and officials from the Department for Business, Innovation \& Skills to agree on a set of devolved powers and responsibilities from central government, to a combined authority of local councils within a functional economic area.

The Act is an enabling one, in that it empowers groups of local authorities to take action to draw up proposals for and establish a combined authority and make a bid for the transfer of powers to these areas where an agreement has been reached with central government through a 'Devolution Deal'. The Act is does not provide any detail or prescription of which powers are to be devolved. It is here that the Act has the potential to enable what has been coined by central government as 'bespoke devolution', whereby local councils can join together to negotiate the terms of devolution to their combined authority on an area-by-area basis. As this paper goes on to discuss, upon reviewing the agreed deals to date, this potential does not yet appear to have been realised. The next section explores in more detail 
the characteristics and details of the agreed Devolution Deals to date, in order to highlight common themes and distinctions.

\section{The 'Devolution Deals' to date}

The Greater Manchester Combined Authority (GMCA) deal which was signed in 2014 has recently been joined by nine additional devolution deals signed by government; North East Combined Authority, Tees Valley Combined Authority, Sheffield City Region Combined Authority, Greater Lincolnshire Combined Authority, East Anglia Combined Authority, Liverpool City Region Combined Authority, West Midlands Combined Authority, West of England Combined Authority and Cornwall Council. The details of these deals are discussed comparatively later within the section of this paper titled Cut and Paste devolution.

The government received a total of 38 devolution proposals from local areas in England, which were required in time for a rather arbitrary September 2015 deadline. That date gave localities just seven weeks to consult with neighbouring authorities, identify viable options for a devolution deal and agree on a proposal. It has been highlighted by many commentators within and outside of local government that this narrow timeframe has not been conducive with allowing for meaningful public engagement; there are approximately 16.1 million people living in areas subject to devolution deals with whom there has been little or no dialogue about what devolution might mean for them, their local communities and the future provision and accountability of public services.

In analysing the devolution deals to date it is clear that they represent a significantly similar set of responses to a centrally framed objective to support both local and national economic growth alongside further streamlining of public service provision at the local level. There has demonstrably been a continued push to see the mayoral model adopted locally, which has resulted in nine new mayors of combined authorities, spanning multiple local authority areas, all of whom will be elected in 2017 .

Below, table 1 displays a review of the content of devolution deal-making up to $15^{\text {th }}$ May 2016. The table encompasses those devolution deals that have been signed by parliament, having moved through the parliamentary process of negotiation and subsequent approval. The main aspects which have been investigated are the geographical/ administrative make-up of established or proposed combined authority areas, the established or proposed governance arrangements, and the areas of power which have been granted or requested as part of the deal-making process with central government. As future devolution deals moved through the parliamentary processes and are agreed with government, 

approach

their details will be included within this table in order to provide a broad and detailed picture of the current process of English devolution.

Table 1: Review of agreed devolution deals to date (15 $5^{\text {th }}$ May 2016)

\begin{tabular}{|c|c|c|c|c|c|c|c|c|c|c|c|c|c|c|c|c|}
\hline Bid Areas & Members & Governance & $\frac{n}{\bar{n}}$ & $\begin{array}{l}\stackrel{\infty}{0} \\
\stackrel{0}{0} \\
0 \\
0 \\
1\end{array}$ & 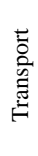 & 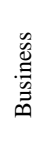 & $\begin{array}{l}\bar{U} \\
\text { 足 }\end{array}$ & 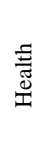 & 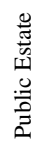 & $\underset{\widetilde{\Xi}}{\vec{\Xi}}$ & 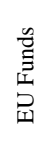 & 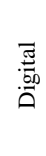 & $\underset{ت}{\mathbb{E}}$ & 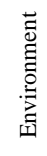 & $\begin{array}{ll}0.0 \\
\sum_{0}^{0} \\
\infty \\
0 \\
0 \\
0\end{array}$ & 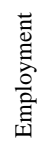 \\
\hline $\begin{array}{l}\text { Greater } \\
\text { Manchester } \\
\text { Combined } \\
\text { Authority }\end{array}$ & $\begin{array}{c}\text { Bolton, Bury, } \\
\text { Manchester, } \\
\text { Oldham, } \\
\text { Rochdale, Salford, } \\
\text { Stockport, } \\
\text { Tameside, } \\
\text { Trafford, Wigan }\end{array}$ & $\begin{array}{c}\text { Mayor } \\
\text { (directly } \\
\text { elected) will } \\
\text { be Chair and } \\
\text { Member of } \\
\text { GMCA } \\
\text { Leadership } \\
\text { Board } \\
\end{array}$ & $\checkmark$ & $\checkmark$ & $\checkmark$ & $\checkmark$ & $\checkmark$ & $\checkmark$ & $\checkmark$ & & $\checkmark$ & $\checkmark$ & $\checkmark$ & $\checkmark$ & $\checkmark$ & $\checkmark$ \\
\hline $\begin{array}{l}\text { North East } \\
\text { Combined } \\
\text { Authority }\end{array}$ & $\begin{array}{c}\text { County Durham, } \\
\text { Gateshead, } \\
\text { Newcastle, North } \\
\text { Tyneside, } \\
\text { Northumberland, } \\
\text { South Tyneside } \\
\text { and Sunderland }\end{array}$ & $\begin{array}{c}\text { Mayor } \\
\text { (directly } \\
\text { elected) will } \\
\text { be Chair and } \\
\text { Member of } \\
\text { NECA } \\
\text { Leadership } \\
\text { Board } \\
\end{array}$ & $\checkmark$ & $\checkmark$ & $\checkmark$ & $\checkmark$ & $\checkmark$ & & & $\checkmark$ & $\checkmark$ & & $\checkmark$ & & $\checkmark$ & $\checkmark$ \\
\hline $\begin{array}{l}\text { Tees Valley } \\
\text { Combined } \\
\text { Authority }\end{array}$ & $\begin{array}{c}\text { Hartlepool, } \\
\text { Middlesbrough, } \\
\text { Redcar and } \\
\text { Cleveland, } \\
\text { Darlington, } \\
\text { Stockton-On-Tees }\end{array}$ & $\begin{array}{c}\text { Mayor } \\
\text { (directly } \\
\text { elected) will } \\
\text { be Chair and } \\
\text { Member of } \\
\text { TVCA } \\
\text { Leadership } \\
\text { Board }\end{array}$ & $\checkmark$ & $\checkmark$ & $\checkmark$ & $\checkmark$ & & & & & & & $\checkmark$ & $\checkmark$ & & $\checkmark$ \\
\hline $\begin{array}{l}\text { Liverpool } \\
\text { City Region } \\
\text { Combined } \\
\text { Authority }\end{array}$ & $\begin{array}{l}\text { Halton, Knowsley, } \\
\text { Liverpool, Sefton, } \\
\text { St. Helens, Wirral }\end{array}$ & $\begin{array}{c}\text { Mayor } \\
\text { (directly } \\
\text { elected) will } \\
\text { be Chair and } \\
\text { Member of } \\
\text { LCRCA } \\
\text { Leadership } \\
\text { Board } \\
\end{array}$ & $\checkmark$ & $\checkmark$ & $\checkmark$ & $\checkmark$ & $\checkmark$ & $\checkmark$ & $\checkmark$ & $\checkmark$ & $\checkmark$ & $\checkmark$ & $\checkmark$ & $\checkmark$ & & $\checkmark$ \\
\hline $\begin{array}{l}\text { Sheffield } \\
\text { City Region } \\
\text { Combined } \\
\text { Authority }\end{array}$ & $\begin{array}{c}\text { Barnsley, } \\
\text { Bassetlaw, } \\
\text { Bolsover, } \\
\text { Chesterfield, } \\
\text { Derbyshire Dales, } \\
\text { Doncaster, North } \\
\text { East Derbyshire, } \\
\text { Rotherham, } \\
\text { Sheffield }\end{array}$ & $\begin{array}{c}\text { Mayor } \\
\text { (directly } \\
\text { elected) will } \\
\text { be Chair and } \\
\text { Member of } \\
\text { SCRCA } \\
\text { Leadership } \\
\text { Board }\end{array}$ & $\checkmark$ & $\checkmark$ & $\checkmark$ & $\checkmark$ & $\checkmark$ & & & & & & & & & $\checkmark$ \\
\hline $\begin{array}{l}\text { East Anglia } \\
\text { Combined } \\
\text { Authority }\end{array}$ & $\begin{array}{c}\text { Cambridgeshire } \\
\text { County, East } \\
\text { Cambridgeshire, } \\
\text { Huntingdonshire, } \\
\text { Broadland, } \\
\text { Fenland, Great } \\
\text { Yarmouth, North }\end{array}$ & $\begin{array}{c}\text { Mayor } \\
\text { (directly } \\
\text { elected) will } \\
\text { be Chair and } \\
\text { Member of } \\
\text { EACA } \\
\text { Leadership } \\
\text { Board }\end{array}$ & $\checkmark$ & $\checkmark$ & $\checkmark$ & $\checkmark$ & $\checkmark$ & $\checkmark$ & & & & & & & & $\checkmark$ \\
\hline
\end{tabular}




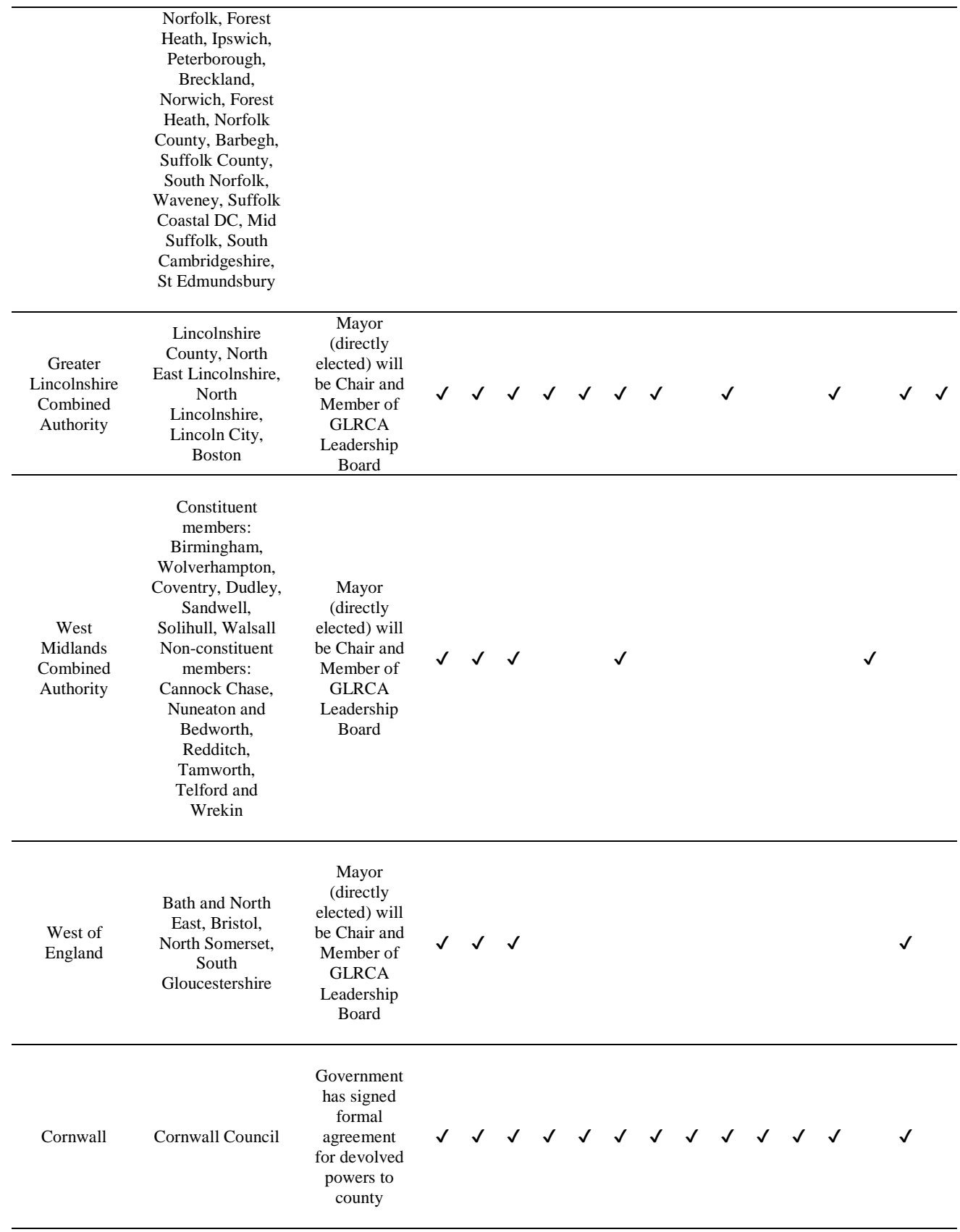

Source: HM Treasury, Devolution Deals (2014; 2015; 2016) 

approach

\section{Cut and Paste Devolution}

Despite a promise from the current Secretary of State for Communities and Local Government, Rt Hon Greg Clarke MP, of 'bespoke devolution', table 1 demonstrates that the commonalities between the agreed deals are obvious; with the exception of Tees Valley and Liverpool who have requested devolved responsibilities around culture, and Cornwall who have identified responsibilities relating to renewable energy and energy efficient homes, almost all of the agreed deals to date reflect a common tariff of devolved tasks from the centre. All of the deals have included devolved responsibility for aspects of transport and infrastructure, business support and education and skills. Most, but not all, of the deals to date have included devolved functions in relation to housing and planning, employment and welfare support and the integration of health and social care.

Although there are noticeable variations of the finer terms of how different combined authorities approach these common themes, within the individual deals, the similarities dwarf these differences. There is a common script which almost all agreed deals to date have followed; $£ 30$ m funding per year for 30 years; greater powers over local transport, buses and trains; new powers over skills and training; and, more control over strategic planning. It is not only the themes of the agreed deals which are remarkably similar, but much of the wording is so akin that upon redacting the names of the respective combined authorities, when trying to identify it's author you would be forgiven for listing any of the combined authority areas that have a agreed deals to date. The promise of bespoke devolution has manifested into a template-style, cut and paste approach for the agreement and publication of devolution deals which, whilst seeing local areas battling against the chronic centralism within Whitehall and reluctance amongst government departments to relinquish control, has resulted in a set of deals which lack any obvious sense of local or bespoke identity.

Commentators both within and outside of English local government, such as the independent, non-partisan urban policy research unit, Centre for Cities, have made attempts to defend what they perceive to be important differences between the agreed devolution deals. Such differences can be seen within the Greater Manchester Devolution deal, which, in being significantly larger than the rest of the deals in its scope, includes substantial devolved responsibility over the integration and provision of Health and Social Care as well as blue light services (HM Treasury, 2014). The West Midlands Combined Authority deal now includes commitment for a $£ 4.4$ billion HS2 Growth Strategy to 'ensure maximum economic benefit from High Speed 2 (HS2) rail investment', while the North East Combined Authority deal boasts a commitment for the rollout of ultrafast broadband across the combined authority area - this is seen to be a particular 
priority for the region given the diverse blend of urban and rural areas (HM Treasury, 2015; HM Treasury, 2015).

These responsibilities are just that - responsibilities, and often they cover specific projects with a particular timeframe. Fundamentally, although the budgets to be devolved amount to large sums of public money, they are still blocks of funding being delegated from Whitehall, and are tied to specific projects and developments. None of the agreed deals have attempted to make a grab at the real prize, fiscal devolution, other than proposals for the retention of growth in business rates - a move which risks further enhancing inequalities between different localities - and levies on infrastructure precepts; both of which are currently the only options for financial devolution available to local government. Local political leaders and authorities require the necessary powers to raise and spend their own revenues, in order to ensure economic prosperity and accountability for the services, which they provide, and/or commission, yet fiscal devolution generally remains untouched; the only fiscal autonomy granted to mayors within the new legislative framework is to introduce a local precept on council tax.

Immediately therefore it might appear that local authorities are not taking full advantage of the current move towards devolution, and that the deals being submitted are not ambitious enough. Given what was a short period of time to prepare deals to meet an arbitrary deadline, this analysis does not seem fair. Although it may be expected that the natural consequence of a deal-making process would be a bottom-up approach, from the evidence above, negotiations to date have suggested that this is not the case. As a recent report produced by the Communities and Local Government Committee highlights, the Committee has heard that requests for specific powers have been frequently and repeatedly blocked by central government departments who seem unwilling to entrust these powers upon local government (CLGC, 2015).

\section{No mayor, no deal}

The current devolution agenda within England is providing a new scene for what has previously been considered as an unsuccessful mayoral experiment (Copus, 2006) for English local government, and despite previous legislative attempts to stimulate the adoption of directly elected leaders across local government since the Local Government Act 2000, out of a total of 352 principal council leaders in England, only 16 are directly elected mayors; this figure does not include the Mayor of London or the proposed mayors in Greater Manchester, Liverpool City Region, and other large urban areas, which are covered by separate legislation and have different powers to local authority mayors. 

approach

Central government has been especially clear in that, in order for combined authorities to be granted significant powers and funding, constituent councils must agree to create the office of a directly elected mayor for their combined authority. Although ministers have insisted that the mayoral model will not be forced upon local areas, where a combined authority area has made proposals to receive an ambitious and extensive suite of devolved powers and funding, local councils are being effectively held at ransom over the issue of whether they will adopt a directly elected mayor.

The Cities and Local Government Devolution Act 2016 presents a new variant to the existing mayoral model in England; whereas current mayors of local authorities do not enjoy additional powers to that of a council leader, the bill makes provisions for a new wave of combined authority mayors who could enjoy greater control over functions such as local transport, housing, skills and healthcare. In addition to devolved functions, when we consider that the new combined authority mayors will also have control over very large sums of public money (see table 2)- tens, even hundreds, of billions of pounds over the next five years, the accountability that a directly elected office provides becomes instrumental.

Where previous attempts to establish elected mayors widely within England have enjoyed limited success (Copus, 2006; Kukovic et al 2015), this new, more empowered variation of directly elected leadership in English local government contains the potential to galvanize the mayoral experiment. In examining the proposed powers for a number of new combined authority mayors, however, we can again see an aspect where the potential of devolution to English local government is not being fully realised; with the exception of the Greater Manchester Combined Authority, the proposed combined authority mayors appear somewhat neutered. Table 2 below outlines the powers of the new combined authority mayors in England. 
Table 2: Devolved powers and functions of new combined authority mayors

\begin{tabular}{|c|c|c|c|c|c|c|c|c|}
\hline & $\sum_{0}^{\longleftarrow}$ & 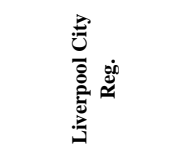 & 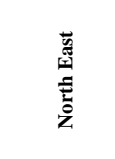 & 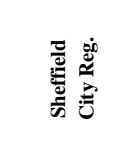 & 层 & 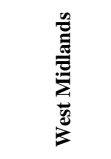 & 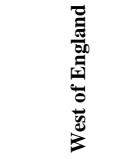 & 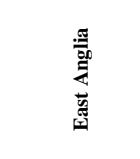 \\
\hline $\begin{array}{c}\text { Investment } \\
\text { fund } \\
\text { (30 years) }\end{array}$ & $£ 900 \mathrm{~m}$ & $£ 900 \mathrm{~m}$ & $£ 900 \mathrm{~m}$ & $£ 900 \mathrm{~m}$ & $£ 450 \mathrm{~m}$ & $£ 1.1 \mathrm{bn}$ & $£ 900 \mathrm{~m}$ & $£ 900 \mathrm{~m}$ \\
\hline Education & $\begin{array}{l}\text { Apprenticeships, } \\
\text { adult skills, further } \\
\text { education }\end{array}$ & $\begin{array}{l}\text { Apprenticeships, } \\
\text { adult skills, further } \\
\text { education }\end{array}$ & $\begin{array}{l}\text { Adult skills, } \\
\text { further } \\
\text { education }\end{array}$ & $\begin{array}{l}\text { Apprenticesh } \\
\text { ips, adult } \\
\text { skills, further } \\
\text { education }\end{array}$ & Adult skills & Adult skills & $\begin{array}{l}\text { Apprenticeship } \\
\text { s, adult skills, } \\
\text { further } \\
\text { education }\end{array}$ & $\begin{array}{l}\text { Apprenticeship } \\
\text { s, adult skills, } \\
\text { further } \\
\text { education }\end{array}$ \\
\hline Housing & $\begin{array}{l}£ 30 \mathrm{~m} \text { a year } \\
\text { investment fund, } \\
\text { strategic planning, } \\
\text { compulsory } \\
\text { purchase powers }\end{array}$ & $\begin{array}{l}\text { Strategic planning, } \\
\text { compulsory } \\
\text { purchase powers, } \\
\text { mayoral } \\
\text { development } \\
\text { corporations }\end{array}$ & $\begin{array}{l}\text { Strategic } \\
\text { planning, } \\
\text { compulsory } \\
\text { purchase } \\
\text { powers }\end{array}$ & $\begin{array}{l}\text { Strategic } \\
\text { planning, } \\
\text { compulsory } \\
\text { purchase } \\
\text { powers, } \\
\text { mayoral } \\
\text { development } \\
\text { corporations }\end{array}$ & $\begin{array}{l}\text { Mayoral } \\
\text { developmen } \\
\mathrm{t} \\
\text { corporation } \\
\mathrm{s}\end{array}$ & $\begin{array}{l}\text { Compulsor } \\
\text { y purchase } \\
\text { powers }\end{array}$ & $\begin{array}{l}\text { Strategic } \\
\text { planning, } \\
\text { compulsory } \\
\text { purchase } \\
\text { powers, } \\
\text { mayoral } \\
\text { development } \\
\text { corporations }\end{array}$ & $\begin{array}{l}\text { Strategic } \\
\text { planning, } \\
\text { mayoral } \\
\text { development } \\
\text { corporations }\end{array}$ \\
\hline Transport & $\begin{array}{l}\text { Consolidated } \\
\text { transport budget, } \\
\text { bus franchising, } \\
\text { smart ticketing }\end{array}$ & $\begin{array}{l}\text { Consolidated } \\
\text { transport budget, } \\
\text { local roads } \\
\text { network, bus } \\
\text { franchising, smart } \\
\text { ticketing }\end{array}$ & $\begin{array}{l}\text { Consolidate } \\
\text { d transport } \\
\text { budget, bus } \\
\text { franchising, } \\
\text { smart } \\
\text { ticketing }\end{array}$ & $\begin{array}{l}\text { Consolidated } \\
\text { transport } \\
\text { budget, local } \\
\text { roads } \\
\text { network, bus } \\
\text { franchising, } \\
\text { smart } \\
\text { ticketing }\end{array}$ & $\begin{array}{l}\text { Consolidate } \\
\text { d transport } \\
\text { budget }\end{array}$ & $\begin{array}{l}\text { Consolidate } \\
\text { d transport } \\
\text { budget, } \\
\text { local roads } \\
\text { network, } \\
\text { bus } \\
\text { franchising, } \\
\text { smart } \\
\text { ticketing }\end{array}$ & $\begin{array}{l}\text { Consolidated } \\
\text { transport } \\
\text { budget, local } \\
\text { roads network, } \\
\text { bus } \\
\text { franchising, } \\
\text { smart ticketing }\end{array}$ & $\begin{array}{l}\text { Consolidated } \\
\text { transport } \\
\text { budget, local } \\
\text { roads network, } \\
\text { bus franchising, } \\
\text { smart ticketing }\end{array}$ \\
\hline $\begin{array}{l}\text { Health and } \\
\text { Social Care }\end{array}$ & $\begin{array}{l}£ 6 \text { bn integrated } \\
\text { health and social } \\
\text { care budget }\end{array}$ & $\begin{array}{l}\text { Planning for } \\
\text { health and social } \\
\text { care integration }\end{array}$ & $\begin{array}{l}\text { Planning } \\
\text { for health } \\
\text { and social } \\
\text { care } \\
\text { integration }\end{array}$ & & & & & \\
\hline
\end{tabular}

Source: HM Treasury, Devolution Deals (2014; 2015; 2016)

There has been significant and widespread tensions between local councils over the prospect of a directly elected mayor, so much so that this has brought a number of devolution deal negotiations to a halt as local authorities have reversed their commitment to having an elected mayor after signing deals with government, as was the case with Hampshire and the Isle of Wight's devolution deal. The mayoral ultimatum presented by central government has proven particularly problematic in rural areas such as Hampshire, where interviews with local politicians revealed that both councillors and council leaders are concerned that an elected mayor is not a suitable model of governance.

The current opposition from councillors towards elected mayors is historic (Rao, 2003) and local campaigns have often gone out of their way to stifle any public excitement about the prospect of being able to directly elect a political leader (Copus, 2006). Despite this opposition from councillors, there appears to be a slow shift emerging in the perceptions of the mayors amongst the local residents to whom councillors owe their election to office. Research consultancy ComRes 

approach

conducted a poll, commissioned by the Centre for Cities, of more than 2,500 citizens across the five biggest city-regions in England who anticipate the introduction of elected mayors in May 2017. The poll found that 57 per cent of the respondents backed giving mayors more powers than councils, with only 25 per cent opposed (COMRES, 2016). These results represent a significant shift from previous public referendums on the matter, many of which have resulted in a resounding 'no'.

Despite opponents of devolution continuing to argue vehemently that the new elected mayors will be too powerful, the outline of powers that are expected to be devolved to combined authority mayors as highlighted in table 2 suggest that the real issue is actually whether they will have enough scope to deliver on public expectations at all. Most new combined authorities appear to be using the Manchester Agreement and Constitution when it comes to setting out the powers of the mayor. It is the task of the constituent authorities of any combined authority to develop their constitution for governance arrangements and the draft constitution then has to be agreed by all of the constituent authorities and then receive the approval of the Secretary of State. The pattern emerging in the drafting of combined authority constitutions is that mayors' cabinets - effectively boards of the constituent council leaders - are being given a series of qualified majority voting powers (effectively a veto), normally with a $2 / 3$ rds majority, over aspects of mayoral powers and these veto powers can vary between combined authorities.

So when considering whether a mayor will be all powerful or lacking in real powers, the answer rests in the constitutions of the individual combined authorities drafted by the constituent councils. It appears that in most cases it is likely that the mayor would be 'neutered' rather than 'all powerful' and councils are working to ensure that mayoral powers are constrained rather than given free reign.

\section{Conclusion}

Devolution in England has yet to take flight, and so to draw any definitive conclusions about its success or failure is premature. History tells us that the numerous attempts within Whitehall to recast and remould local government within the United Kingdom have had significant and often negative consequences for local democracy. Whilst the concept of devolution may mean different things to different minds, there is a general acceptance that the shift of power from the centre to the localities is critical to renewing local democracy. Even more critical is the need for that shift to be shaped from the bottom up by local politicians and local residents. The new legislative framework for this shift in England has the potential to provide local councils with an opportunity to create a bespoke devolution deal for their areas, which reflects local needs and identities. However, simply legislating for the devolution of power is not enough on its own, and a cultural change in the relations between the localities and the centre is required to 
ensure the longevity and sustainability of a devolution settlement for English local government.

The deals agreed to date, and the top-down process of the negotiations, have demonstrated that the bespoke element of devolution is somewhat lacking, and a common menu of powers that appease the broad policy objectives of central government have emerged. The process for negotiating devolved powers with Whitehall departments has demonstrated a continued reluctance of the civil service to relinquish the power over policy areas to local government, and unelected political elites are having significant influence in shaping the devolution deals in parallel with what has been a total absence of public engagement on what the consequences of these deals will be for local communities.

Attempting to spot the difference between the devolution deals struck at this stage is difficult, but so too is it difficult to see where the current government's devolution policy differs in any great extent to previously unsuccessful attempts at restructuring local government. Devolving a selective menu of responsibilities to quasi-regional oligarchies whilst eradicating local council budgets, with no imminent signs of genuine fiscal devolution, is not only dangerous for local government but also demonstrates little change, in principle, to the centralised relationship between Whitehall and our municipalities. On the evidence so far, the devolution agenda has a long way to go before it develops as a radical and fundamentally new relationship between local and central government.

\section{References}

Bogdanor, V. (2009) The New British Constitution (Portland: Hart Publishing).

Bogdanor, V. (1999) Devolution in the United Kingdom (New York: Oxford University Press).

Chisholm, M. (2010) Emerging realities of local government reorganization, Public Money \& Management, 30(3), pp. 143-150.

Communities and Local Government Committee (2016) Devolution: the next five years and beyond (London: The Stationary Office).

ComRes (2016) Centre for Cities: 2017 mayoral research (London: ComRes).

Copus, C. (2016) In Defence of Councillors (Manchester: Manchester university press).

Copus, C. (2006) Leading the localities: executive mayors in English local governance (Manchester: Manchester university press).

Copus, C. (2004) Directly elected mayors: a tonic for local governance or old wine in new bottles? Local Government Studies, 30(4), pp. 576-588.

Dunleavy, P. (1980) Urban Political Analysis. 1st ed. (London and Basingstoke: Palgrave Macmillan UK).

Elcock H., Fenwick, J. \& McMillan, J. (2010) The reorganization addiction in local government: unitary councils for England, Public Money \& Management, 30(6), pp. 331-338 

approach

Griggs, S. (2015) Two tribes? Exploring the future role of elected members (Hamilton: Association for Public Sector Excellence).

Goldsmith, M. \& Page, E. (1987) Britain, in: M. Goldsmith \& E. Page (Eds) Central and Local Government Relations: A Comparative Analysis of West European Unitary States (London: Sage).

HM Government (2016) The Cities and Local Government Devolution Act 2016 (London: The Stationary Office).

HM Treasury (2016) East Anglia Devolution Agreement. 2016 (London: HM Treasury).

HM Treasury (2016) Greater Lincolnshire Devolution Agreement (London: HM Treasury).

HM Treasury (2016) Greater Manchester Agreement: devolution to the Greater Manchester Combined Authority and transition to a directly elected mayor (London: HM Treasury).

HM Treasury (2016) Liverpool City Region devolution agreement (London: HM Treasury).

HM Treasury (2016) West of England devolution agreement (London: HM Treasury).

HM Treasury (2015) North East devolution agreement (London: HM Treasury).

HM Treasury (2015) Sheffield City Region devolution agreement (London: HM Treasury).

HM Treasury (2015) Tees Valley Region devolution agreement (London: HM Treasury).

HM Treasury (2015) West Midlands Combined Authority devolution agreement (London: HM Treasury).

Jones, G. \& Stewart, J. (1985) The case for local government. 2nd ed. (London: George Allen \& Unwin).

Jones, G. \& Stewart, J. (2002) Central-Local Relations Since the Layfield Report, Local Government Studies, 28(3), pp. 7-28.

S. Kukovic, C., Copus, M. Hacek \& A. Blair (2015), Direct Mayoral Elections in Slovenia and England: Traditions and Trends compared, Lex Localis - Journal of Local Self-Government, 13(3), pp. 697-718.

Leach, S. (2006) The changing role of local politics in Britain (Bristol: The Policy Press).

Lowndes, V. \& Leach, S. (2004) Understanding local political leadership: constitutions, contexts and capabilities, Local Government Studies, 30(4), pp. 557-575.

Rao, N. (2003) Options for change: mayors, cabinets or the status quo?, Local Government Studies, 29(1), pp. 1-16.

Stewart, J. (2014) An era of continuing change: reflections on local government in England 1974-2014, Local Government Studies, 40(6), pp. 835-850.

Stoker, G. (1991) The politics of local government. 2nd ed. (Basingstoke: Macmillan).

Waterman, C. (2014) Local government and local governance: 1944-2011, Local Government Studies, 40(6), pp. 938-953.

Weir, S. \& Beetham, D. (1999) Political Power and Democratic Control in Britain: The Democratic Audit of Great Britain (London: Routledge). 